\title{
LOST IN COLONIALISM. FRANCISCO SILVELA Y DE LE VIELLEUZE Y LA CUESTIÓN MARROQUÍ (1896-1900) ${ }^{1}$
}

\author{
Francisco Manuel Pastor Garrigues
}

IES «Sanchis Guarner» de Silla, Valencia

franciscomanuelpastor@yahoo.es

A mis padres

El centenario de la muerte de Francisco Silvela en el año 2005 tuvo poco impacto en la sociedad y en la historiografía. Entre la escasa producción que se dedicó a su figura destaca el desarrollado estudio introductorio que le ba dedicado Luis Arranz en la edición de los Escritos y discursos políticos. En este texto estudiamos la participación de Silvela en la apertura de la cuestión marroqui y se insiste en el fracaso de su iniciativa para apoderarse de los territorios de Tarfaya y la Sagîa al-Hamra en 1900. Ello llevó a que el gabinete liberal de Sagasta durante el bienio 1901-1902 emprendiese un proceso negociador con Francia en el que se discutió el reparto de Marruecos.

Palabras Clave: Silvela, Imperialismo, ofensiva diplomática de 1900, Tarfaya, Sagîa alHamra.

\section{Lost in Colonialism. Francisco Silvela y de le Vielleuze and the Moroccan QUESTION (1896-1900)}

The centenary of Francisco Silvela's death, in 2005, had little impact on society and the writing of history. Amidst the few pieces produced on this outstanding figure, the introductory study that Luis Arranz wrote to the new edition of Escritos y discursos políticos stands out. In this paper, we study the role of Silvela in the Moroccan question opening. From

1. Agradezco encarecidamente las observaciones, comentarios y referencias bibliográficas proporcionadas por los anónimos evaluadores de esta revista.

[Recibido: 22/6/17; Aceptado: 2/1/18] 
1900 the Silvela government undertook a diplomatic offensive attempting to take advantage of the Sultanate's weakness to wrench the vast territories of Tarfaya and Sagîa al-Hamra from it. The failure of this attempt would lead Sagasta's liberal cabinet during the two years 1901-1902 to getting a Spanish-French negotiating process underway in which the distribution of Morocco was discussed.

KEYWORDS: Silvela, Imperialism, diplomatic offensive of 1900, Tarfaya, Sagîa al-Hamra.

\section{Introducción}

Siguiendo a Fidel Gómez Ochoa, podemos convenir que Francisco Silvela y de le Vielleuze ha padecido y sigue padeciendo un significativo arrinconamiento historiográfico. Un hecho este que no es ajeno a ciertos avatares del contemporaneísmo español indicativos de su aún exigua densidad y magnitud, así como de una excesiva influencia sobre su agenda y sobre su mirada de los debates políticos del momento. Podría decirse que Silvela no ha tenido buena suerte con la profesión histórica. La importancia del hombre que en 1899 impidió que hubiera una salida autoritaria a la crisis finisecular nunca ha sido ignorada ni puesta en discusión, pero cuando Florentino Portero, durante largo tiempo su principal estudioso y conocedor ${ }^{2}$ - de él se ocupó en su tesis de licenciatura y en un notable conjunto de artículos de revistas y capítulos de libros en los años ochenta y noventa-, 3 pasó a ocuparse de otros temas, nadie compartía su empeño ni le relevó en la tarea de investigar exhaustivamente al político madrileño. Silvela no ha sido una referencia para las derechas españolas del siglo XX y este desinterés ha alcanzado a la historiografía, quedando ensombrecido por las poderosas y atractivas (para el investigador) figuras de Antonio Cánovas y Antonio Maura, a quien además se le tiene por la encarnación del conservadurismo regeneracionista. Asimismo, a Silvela hasta ahora no le ha acompañado polémica alguna, ni política ni historiográfica, en las que, con beneficio para su estudio, sí se han visto envueltos sus colegas citados. Como resultado de todo ello, hasta el momento Silvela ha sido fundamentalmente objeto de acercamientos parciales, ya a ciertos aspectos de su amplia y diversa actividad — sobresalen entre ellos sus a la postre

2. Portero, Florentino, «Francisco Silvela, jefe del conservadurismo español», Revista de Historia Contemporánea, n. ${ }^{\circ}$ 2, Universidad de Sevilla, 1983, pp. 146-166; Portero, Florentino, «El regeneracionismo conservador: el ideario político de Francisco Silvela», en Tusell, Javier, Feliciano Montero y José María Marín (eds.), Las derechas en la España contemporánea, Madrid, UNED/Anthropos, 1997, pp. 45-58; Portero, Florentino, «El conservadurismo español ante la crisis de fin de siglo», en Tusell, Javier y Florentino Portero (eds.), Antonio Canovas y el sistema político de la Restauración, Madrid, Biblioteca Nueva, 1998, pp. 349-392.

3. Portero no se contenta en su trabajo investigativo — como la gran mayoría de los que se han preocupado de la obra de Silvela - con el fácil recorrido de los hechos inmediatos de su vida, sino que parte de un cuestionarse esa existencia desde un variado prisma de posibilidades esclarecedoras. Todos los hechos, que en sus trabajos se nos muestran como resultado de una metódica búsqueda, son analizados en profundidad, dotándolos de una carga de humanidad que no desequilibra el contenido estrictamente científico que impera a lo largo de sus estudios. 
trascendentales planteamientos acerca de Marruecos, investigados por Jesús María Martínez Milán, ${ }^{4}$ Javier Anta Ugarte, ${ }^{5}$ Ángel Luis Clemente Ortega y José Ignacio de Frutos de Blas ${ }^{6}$ y su intervención en la elaboración de los códigos civil y penal一, ya a algunas partes o aspectos de su vida política —en particular el impacto en el ámbito provincial de su acceso a la jefatura conservadora-. Los estudios sobre su conservadurismo y su trayectoria han consistido en artículos de revistas o en capítulos de libros, casi todos incluidos en obras de autoría colectiva sobre las derechas españolas o sobre la política de la Restauración. Muy pocas veces objeto de interés específico, Silvela ha sido en todo caso de esta forma examinado por algunos de los principales expertos en el conservadurismo liberal como Carlos Seco Serrano, ${ }^{7}$ Carlos Dardé ${ }^{8}$ o Luis Arranz, ${ }^{9}$ quienes de esa forma han contribuido, junto con el citado Portero, a la no sencilla tarea de ir estableciendo el carácter y los perfiles de su conservadurismo y de su propuesta de reforma del funcionamiento de la monarquía constitucional de 1876, así como lo que significaron para la marcha del Partido Conservador y del régimen de la Restauración. Como resultado de todos esos análisis, Silvela sería el fundador y primer gran exponente de un conservadurismo crítico con el canovismo, de carácter regeneracionista y de vocación reformista y modernizadora, que eclosionó en torno a la crisis del 98. Tras hacerse a la muerte de Cánovas con la jefatura del conservadurismo dinástico, fue llamado a gobernar gracias a lo que significaba «el fortalecimiento del régimen combatiendo el clientelismo y la corrupción y su no contaminación en la cuestión cubana». Como gobernante ofreció una

4. Martínez Milán, Jesús María, «España y Francia en el sur de Marruecos: intereses, delimitación de fronteras y contencioso territorial, 1900-1912», Estudios de Asia y África, vol. 50, n. ${ }^{\circ}$ 1, México D.F., 2015, pp. 117-139.

5. Anta Ugarte, Javier, Gonzalo de Reparaz: intelectual errante, Tesis doctoral inédita, Barcelona, Universitat de Barcelona, 2016.

6. Clemente Ortega, Ángel Luís y José Ignacio de Frutos de Blas, «Francisco Silvela y Marruecos: un proyecto de política exterior», Isla de Arriarán. Revista Cultural y Científica, n. ${ }^{\circ}$ 14, Málaga, 1999, pp. $226-254$.

7. Seco Serrano, Carlos, «Regeneracionismo y tensiones sociales (en torno al Gobierno Silvela de 1899 a 1900)», Estudios de Historia Moderna y Contemporánea, n. ${ }^{\circ}$ 113, Madrid, 1978, pp. 221-268; Seco Serrano, Carlos, «Los silvelistas catalanes: notas para su estudio», Estudios históricos, n. ${ }^{\circ}$ 1, Madrid, 1990, pp. 169-198; Seco Serrano, Carlos, Historia del conservadurismo español. Una línea integradora en el siglo XIX, Madrid, Temas de Hoy, 2000; Seco Serrano, Carlos, «Francisco Silvela: el regeneracionismo ético. Homenaje en su centenario», Boletín de la Real Academia de la Historia, vol. 202, n. ${ }^{\circ}$ 2, Madrid, 2005, pp. 185-195.

8. Dardé Morales, Carlos, «Los conservadores ante la crisis de 1898: el regeneracionismo de Francisco Silvela», en Homenaje a D. José Luis Comellas, Sevilla, Universidad de Sevilla, 2000, pp. 185-200.

9. Arranz, Luis, «El liberalismo conservador en la Europa continental, 1830-1939: los casos de Francia, Alemania e Italia», Revista de Estudios Políticos, n. ${ }^{\circ}$ 102, Madrid, 1998, pp. 59-76; Arranz, Luis, «Los liberalconservadores y la consolidación del régimen constitucional en la España del siglo XIX», Historia contemporánea, n. ${ }^{\circ}$ 17, Bilbao, 1998, pp. 169-188; Arranz, Luis, «La Restauración, 1875-1902: el triunfo del liberalismo integrador. Canovas y Silvela», en Marco, José María (coord.), Genealogía del liberalismo español, 1875-1936, Madrid, FAES., 1998; Arranz, Luis, «Francisco Silvela (1845-1905) y las incertidumbres del 'regeneracionismo' conservador», en Rus Rufino, Salvador y Javier Zamora Bonilla (coords.), Una polémica y una generación. Razón bistórica del 1898, León, Universidad de León, 1998, pp. 33-38; Arranz, Luis, Escritos y discursos políticos de Francisco Silvela y de la Vielleuze, Madrid, Centro de Estudios Políticos y Constitucionales, 2005; Arranz, Luis, «Silvela, Maura y el revisionismo conservador», en Pendás García, Benigno, Antonio Maura, en el centenario del «Gobierno Largo», Madrid, FAES, 2007, pp. 63-98. 
«solución de recambio» neutralizadora del peligro de dictadura militar y puso en práctica un ambicioso programa sin conseguir alcanzar el gran objetivo de realizar, mediante una «revolución desde arriba» centrada en la reforma de la administración local y provincial, una transformación del sistema que diera al régimen un apoyo social más genuino y extenso. Al no acompañarle el necesario consenso de los propios no pudo llevar a cabo sus planes, pero consiguió que su sucesor al frente del conservadurismo dinástico fuera Antonio Maura y con ello que su línea política fuese la seguida en el futuro por dicha fuerza política. ${ }^{10}$

Por su parte, estas líneas pretenden analizar la relación del líder conservador Francisco Silvela con el hecho imperial, fundamentalmente a partir de su imbricación con el acoso colonialista español sobre el Imperio de Marruecos, a través de lo categórico y de lo operativo, en un margen estrecho de años que abarca de 1896 a 1900, utilizando documentación primaria, básicamente sus intervenciones en el Congreso de Diputados en 1896, sus discursos y conferencias públicas a partir de 1897 y los — hasta hace pocos años- inéditos fondos que se conservan en Alcalá de Henares relativos a su ejercicio de la jefatura del gobierno en 1899-1900, los cuales aportan una notable luz sobre su participación en la dinámica del desmembramiento del Sultanato de Marruecos. Dotado de un fino sentido para leer correctamente el devenir impuesto por el fenómeno imperialista, Silvela entendía a la perfección la complejidad de un mundo cambiante, a partir de entonces, policéntrico en cuanto al reparto del poder y en efervescencia, donde el colonialismo era una muestra de la vitalidad existencial de un país, un signo de identidad europea, y planteaba a todos los países del Viejo Continente, si querían ser respetados, la necesidad de demostrar su poderío económico y militar. El líder conservador vislumbró la necesidad de figurar del lado de los grandes, ser el último de los grandes, con la necesidad ineludible — por ello— de colonizar, ante la certidumbre de, si eso no se hacía, ser colonizado. Así, desde 1896 postuló en el Parlamento la necesidad de un giro fundamental en la política exterior española que permitiese al país abandonar su posición de sucedáneo de potencia, imagen — de facto- de un pasado caduco, para no sólo pensar en futuras expansiones en África, sino conseguir en la dramática situación que se vivía, la seguridad del propio territorio nacional (sobre todo en lo que se refería a Baleares y Canarias), mediante una garantía internacional, lo que suponía el ingreso en la Dúplice franco-rusa. Entre 1897 y 1899 Silvela elucubraría en varias conferencias públicas, estructurando en ellas un corpus teórico sobre el fenómeno colonialista, trufado de influencias de autores como Lanessan o Seeley, y exponente de un nacionalismo conservador, agresivo, racista, plenamente imbuido del darwinismo social, basado sobre todo en un sentimiento de superioridad de la raza blanca (con la misión de ejercer una función hegemónica y dirigente en el mundo) y, al mismo tiempo, de desprecio hacia otros pueblos o razas considerados como inferiores, con una función secundaria y pasiva en la Historia.

10. Gómez Ochoa, Fidel, «Francisco Silvela en la historiografía contemporánea. El impacto del centenario de su muerte y el "Estudio introductorio" de Luis Arranz a los Escritos y discursos políticos», Historia y Política, n. ${ }^{\circ} 22$, Madrid, 2009, pp. 261-278. 
Por último en 1900, siendo jefe del gobierno aplicó todas estas ideas en la praxis, intentando construir en Tarfaya y la Sagîa al-Hamra un imperio de recambio al perdido en el Pacífico y el Caribe, no en aras a obtener su explotación económica, sino más bien a forjar un estratégico glacis o zona de seguridad en la costa occidental de Marruecos que permitiese una mejor defensa avanzada del territorio nacional, sorprendiese a la comunidad europea y devolviese al país su condición de colonizador y una posición de prestigio respetada por toda Europa.

\section{Los escarceos de Silvela con el hecho imperial. Los debates en el Congreso de los Diputados (1896)}

Nuestra primera escala en el análisis de los principios teóricos de la actuación imperialista de Silvela la vamos a realizar en el contexto finisecular del siglo XIX. En aquel momento, las relaciones hispano-marroquíes a comienzos del reinado del Sultán Mawlay Abd al-Aziz ofrecían para España un perfil ambiguo. Un Marruecos más frágil aparecía por primera vez como horizonte colonial capaz de ofrecer una alternativa viable al retroceso de la presencia hispana en Cuba. Y de hecho, España ejercía un relativo peso en los asuntos marroquíes en vísperas del desastre de 1898. La diplomacia restauracionista se beneficiaba así de la política llevada a cabo en los años anteriores, consistente en un enfrentamiento diplomático y en una guerra de espías con Francia, con la pretensión de defender la integridad territorial del Imperio jerifiano y la soberanía del anterior Sultán, Mawlay Hassan I. Pero, al mismo tiempo, era patente la debilidad de los proyectos hispanos en Marruecos frente a los de otras potencias europeas. En la dura competencia por asegurarse la posición preferente en el futuro reparto del Imperio jerifiano, considerado como inevitable a corto plazo, una potencia como Francia desplegó una mezcla de expansionismo militar y «penetración pacífica» que pretendía debilitar el Estado marroquí y colocarlo en situación de dependencia «civilizatoria» a la manera argelina. ${ }^{11}$ Por su parte, Gran Bretaña reconoció la soberanía del Sultán más allá del alcance real y efectivo de la misma, con el fin de asegurarse un trato comercial y diplomático prioritario y, al mismo tiempo, cerrar las puertas a la injerencia de otros países en un punto vital para su entramado imperial. ${ }^{12}$ En ese contexto, la actuación española podría haber sido con la francesa el motor

11. Sobre la actuación francesa en Marruecos a finales del siglo XIX, ver, entre otros, Miège, Jean-Louis, Le Maroc et l'Europe, 1830-1894, vol. 4, París, Presses Universitaires de France, 1964; Burke III, Edmund, Prelude to Protectorate in Morocco. Precolonial protest and resistance, 1860-1912, Chicago/Londres, University of Chicago Press, 1976; Abdelhamid, Smaili Moulay, Les années terribles du Maroc oriental, vols. 1 y 2, Oujda, BMFI, 1996.

12. Sobre la actuación británica en Marruecos antes del Protectorado, ver, entre otros, Parsons, Frederick V., The origins of the Morocco question, 1880-1900, London, Duckworth, 1976; Bendaoud, Abdelwahed y Mohammed Maniar (eds.), Tánger 1800-1956. Contribution à l'bistoire recente du Maroc, Rabat, Éditions Araboafricaines, 1981; Brett, Michael, «Great Britain and the Southern Morocco in the Nineteenth Century, Journal of North African Studies, vol. 2, n. ${ }^{\circ}$ 2, Londres, 1997, pp. 1-10. 
de la descomposición del Imperio marroquí. Sin embargo, en 1895 la presión militar hispana sobre Marruecos cesó, coincidiendo con el hundimiento del crucero Reina Regente, en aguas del Estrecho de Gibraltar..$^{13}$ La magnitud del desastre llevó, de hecho, a recapacitar a las autoridades restauracionistas; en consecuencia, el tema marroquí dejó de inquietar a la diplomacia hispana durante ese año y pasó a ser objeto solamente de especulaciones teóricas, carentes por completo de concreción práctica. En este sentido, la elaboración de una memoria secreta sobre Marruecos por parte del conde de Benomar, ${ }^{14}$ el máximo experto en los asuntos marroquíes de la diplomacia restauracionista, marcó la transición a una etapa en la que los gobiernos de turno prescindieron de toda aspiración política concreta en el Sultanato. ${ }^{15}$ Es más, a lo largo de 1896, España ofreció los peores testimonios de incompetencia colonialista en Marruecos, de ineficacia imperialista, precisamente cuando la agitación social existente en el amplio sur atlántico del Imperio marroquí, atribuida por los servicios de inteligencia hispanos a las intromisiones de agentes republicanos, iba en aumento y se tradujo en la muerte del principal espía español destacado en el territorio, al-Hach Abd Al-lah El Morabet, el cual había dedicado gran parte de su existencia a frustrar los intentos galos de establecer una cabeza de puente en las costas atlánticas del Sultanato vecinas a Canarias. Ante este hecho, la respuesta hispana fue bastante tibia y muy indicativa de su debilidad operativa en Marruecos. No se produjo ni envío de fuerzas expedicionarias para castigar a los asesinos, ni se reanudó la política de las cañoneras intensamente utilizada por los gabinetes restauracionistas en etapas anteriores. ${ }^{16}$

Silvela postuló, en cambio, desde 1896 la necesidad de un giro fundamental en la política exterior española, que permitiese al país no sólo pensar en futuras expansiones en África, sino conseguir en la dramática situación que se vivía, la seguridad del propio territorio nacional, sobre todo en lo que se refería a los archipiélagos balear y canario

13. Como escribe Stanley Payne, «un inexplicable desastre de la Marina rivalizó muy pronto con la pobre demostración (de inoperancia y falta de efectividad) hecha por el Ejercito en el transcurso de la recién terminada guerra de Melilla. Después de llevar a un enviado del Sultán a España, de vuelta a África, nunca volvió a saberse el paradero del nuevo crucero español Reina Regente. Al parecer fue sorprendido por una tormenta repentina cerca de Gibraltar, zozobró y se hundió con toda la tripulación a bordo. Este desastre menor fue aún más deprimente porque el Reina Regente era una de las pocas unidades que se habían añadido (...) recientemente a la flota de guerra española». La cita de Payne está contenida en Lou, Gabriel, Alfonso XIII, Madrid, Círculo de Amigos de la Historia, 1976, p. 44.

14. Archivo de la Real Academia de la Historia (en adelante ARAH), Memoria secreta sobre la cuestión marroquí y modo de resolverla, mayo de 1895, Benomar, 9/7398.

15. El plan secreto de Benomar buscaba configurar el extremo noroccidental de África como un territorio que actuase como «colchón amortiguador» frente a las tensiones coloniales o bélicas que se pudiesen generar en la conclusión de la colonización del septentrión africano entre Gran Bretaña, Francia y posiblemente Alemania; por ello se debía realizar una declaración de neutralidad del Estrecho de Gibraltar y del Imperio jerifiano, que pasaría a convertirse en protectorado de España. La referencia de Benomar era la Conferencia de Berlín de 1884-1885, cuando la inmensa extensión del Congo pasó a ser un dominio personal del rey Leopoldo II de Bélgica, actuando como territorio tapón que separaba los intereses portugueses, germanos, franceses y británicos.

16. En 1887,1889 y 1890 , además de en la guerra de Melilla. 
además de los territorios norteafricanos, mediante una garantía internacional, la que suponía el ingreso en la Dúplice franco-rusa. En ese momento, en el que España estaba más necesitada de auxilios, de cualquier tipo y condición, había perdido el único lazo internacional, más o menos fuerte, que durante ocho años hiciera proclamar con orgullo a los ministros de Estado que, con él, España formaba parte del «concierto europeo»:17 esto es, la aproximación a la Triple Alianza. No cabe plantearse la hipótesis de lo que hubiera sido el desarrollo de la guerra con los Estados Unidos si España hubiera mantenido e incluso incrementado algún tipo de alianza europea. Rotos los lazos que sutilmente la unían a la Tríplice y desvanecida la posibilidad de cimentar sobre bases más sólidas una relación que, si bien con altibajos y no exenta de incidentes, había dado sus frutos en la política marroquí, en palabras de García Sanz, el país «caminaba en solitario al encuentro del desastre». ${ }^{18}$ Mientras se esfumaba, así, toda una línea diplomática que se había ocultado durante años a la opinión pública al tiempo que se predicaba a ésta el neutralismo y la abstención, la sensación de peligro — ante las insurrecciones cubana y filipina y el futuro conflicto armado con los Estados Unidos- había hecho brotar, en la prensa y en las Cortes, el debate abierto sobre política exterior del que solamente había habido manifestaciones ocasionales anteriormente. En este sentido, el debate del discurso de la Corona llevado a cabo en julio de 1896 serviría para poner de manifiesto las distintas concepciones de la política exterior que, según los diversos grupos políticos integrantes de la Cámara baja, debería haber tenido España y habría de seguir en el futuro. En particular llamó la atención el choque de posturas entre el jefe de gobierno, Cánovas y Silvela, que había abandonado el partido conservador cuatro años antes. ${ }^{19}$ Silvela, partidario siempre de una aproximación hispana a la Tercera República, partía de

la evidentísima necesidad de España (en el futuro) (...) de romper el aislamiento y el principio de absoluta neutralidad que han sostenido hasta aquí sus Gobiernos como dogma de su política internacional; que es indispensable que una nación como la nuestra abandone esos derroteros y tome otros rumbos. ¿Quien puede desconocer ya que un país que tiene importantes posesiones en el extremo Oriente, intereses considerables en África; que un país que se halla en las condiciones que el nuestro, que está enlazado con todos los conflictos de la vida europea y con todos los intereses que se han de debatir en todos esos mares y en todos esos continentes, no debe permanecer aislado en medio de las luchas de los demás? No es de ahora, es de mucho tiempo este concepto mío respecto de este particular, y es que de todas las aventuras en que nosotros pudiéramos embarcarnos no hay ninguna seguramente que aventajara en temeridad á la de permanecer aislados. ${ }^{20}$

17. Torre del Río, Rosario de la, «Entre amenazas e incentivos. España en la política internacional, 1895 1914», Studia Histórica, Historia contemporánea, n. ${ }^{\circ}$ 24, Universidad de Salamanca, 2006, pp. 231-256

18. Véase García Sanz, Fernando, Historia de las relaciones entre España e Italia. Imágenes, comercio y politica exterior (1890-1914), Madrid, C.S.I.C., 1993, p. 83.

19. Vid Portero Rodríguez, Florentino, «Francisco Silvela, jefe del conservadurismo español...», cit., p. 147.

20. Diario de Sesiones de las Cortes. Congreso de Diputados, en adelante D.S.C.D., 10 de Julio de 1896. 
El jefe del partido conservador, ${ }^{21}$ contestándole, negaba el hecho de que España permaneciera aislada del mundo:

No hemos estado aislados jamás del movimiento de Europa en aquellas cosas en que hemos coincidido en interés con ésta ó con la otra nación. España no ha estado nunca aislada en las cuestiones de Marruecos, y si se han presentado algunas otras que han ofrecido el mismo interés (...) España, no ha tratado de estar aislada, ni lo ha estado.22

Dentro del Parlamento, la opción de la aproximación a Francia, esto es, de una alianza con la Tercera República, o cuanto menos un acercamiento a la misma no sólo contaba con el respaldo de Silvela; en el grupo carlista, la mayoría de sus integrantes se decantaban por una alianza unilateral con la reaccionaria Rusia Zarista, ${ }^{23}$ en tanto que el líder tradicionalista Vázquez de Mella lo hacía por una — a la par — con los dos miembros de la Dúplice. ${ }^{24}$ Frente a los que como el liberal León y Castillo le recriminaban a Cánovas el aislamiento internacional de España, el líder restauracionista espetaba la inoportunidad

21. Se ha dicho con alguna frecuencia en nuestra historiografía que los hechos relevantes de la historia política de España del siglo XIX, sobre todo los concernientes a sus últimos decenios — concretamente desde el reinado de Alfonso XII- son ya conocidos, por lo que la tarea de los historiadores queda prácticamente circunscrita a su interpretación y significación, a la luz de un contexto de política nacional e internacional de mayor o menor amplitud y/o de una perspectiva histórica más o menos globalizadora. En ese sentido, se ha dado por sentada la acusación a Cánovas, achacándole el hecho de practicar un cierto robinsonismo diplomático, de carecer de una política exterior en sentido estricto, de confinar al país para que este se encerrase dentro de las fronteras nacionales, de mantener una dinámica de ausencia de proyección exterior y, en el menos ensimismado de los casos, de ejercer en política internacional una actitud meramente reactiva. De carecer de una concepción amplia de las alianzas internacionales, y reducirlas a puntos o aspectos determinados, evitando compromisos en las grandes combinaciones diplomáticas europeas. Cfr. Salom Costa, Julio, «La política exterior y ultramarina de Cánovas», en Bullón de Mendoza, Alfonso y Luis E. Togores (coords.), Cánovas y su época, t. II, Madrid, Fundación Cánovas del Castillo, 1999, pp. 1087-1136. Esta calificación sobre la idea que el gobernante conservador de la Restauración tenía de la política exterior de España en aquellos años no se tiene en pie y resulta equivocada e inválida tras la serie de investigaciones realizadas por Javier Rubio, el cual, tras evidenciar las actuaciones de cierto calado y entidad del político malagueño, concluye en que ya no es posible definir la política exterior de Cánovas con el manido y erróneo recogimiento en el que se implica, principalmente «el deliberado apartamiento de alianzas, compromisos y empresas exteriores». Así en los inicios del régimen restauracionista, el político conservador quiso comprometer al país en una estrecha alianza con el II Reich. Cfr. Rubio, Javier, «Los primeros años del reinado de Alfonso XII: su compleja problemática nacional e internacional», Anales de Historia Contemporánea, n. ${ }^{\circ}$ 23, Universidad de Murcia, 2007, pp. 507-560; Rubio, Javier, El final de la era de Cánovas. Los preliminares del «desastre» de 1898, vol. 1 y 2, Madrid, Biblioteca Diplomática española, 2004; Rubio, Javier, «La política exterior de Cánovas del Castillo: una profunda revisión», Studia Histórica. Historia Contemporánea, n. ${ }^{\circ}$ 13-14, Universidad de Salamanca, 1995-1996, pp. 167-197. Cfr. Torre Gómez, Hipólito de la, «El destino de la 'regeneración' internacional de España (1898-1918)» en Proserpina, 1, Especial Monográfico «Relaciones Internacionales de España en el siglo XX», Mérida, UNED, diciembre de 1984, pp. 9-10; véase también Martínez Carreras, José U., «La política exterior española durante la Restauración, 1875-1931», en Vilar, Juan Bautista (ed.), Las relaciones internacionales en la España contemporánea, Murcia, Ediciones Universidad de Murcia, 1989, p. 83.

22. D.S.C.D. 10 de Julio de 1896.

23. Vid. Diego, Emilio de, «La España de 1896», en Hacia el 98. La España de la Restauración y la crisis colonial, 1895-1898), Madrid, Cuadernos de la Escuela Diplomática /12, 1997, p. 100.

24. D.S.C.D. 11 de Julio de 1896. 
de cualquier compromiso, y en ese sentido, venía a respaldarle Sagasta, cuando en un momento en que arreciaban las presiones en busca de aliados, declaraba en El Correo ${ }^{25}$ que no veía fácil ninguna alianza internacional: España no era apetecida como compañera de viaje por parte de los bloques existentes ${ }^{26}$ Cánovas volvió a hacer profesión de fe en su teoría del recogimiento y en la necesidad de neutralidad — a ultranza- de la nación española en los grandes acontecimientos de política internacional, rechazando la posibilidad de inscribirse como aliado en alguno de los sistemas de alianzas existentes:

Lo que yo no he hecho ni he querido hacer jamás, lo que he combatido (con lo cual creo haber obtenido algún éxito á favor de los intereses permanentes de España), ha sido el loco espíritu de aventuras... (...). Nosotros no tenemos los medios normales que debe tener una Nación que quiera intervenir en los intereses universales; nosotros no tenemos sobrantes de rentas, ni baratura de crédito, ni medio alguno para emprender sistemáticamente, en asuntos internacionales, caminos como el que ahora hemos tomado respecto de la isla de Cuba; ese camino, que España ha podido tomar respecto de la isla de Cuba (...), no lo podría tomar respecto de otro género de intereses. Así es que no me produce ninguna impresión en el ánimo el que se me diga que soy partidario del aislamiento. ${ }^{27}$

La debilidad tecnológica y militar, las limitaciones de la expansión económica española aparecían así como los elementos determinantes de la no incorporación de España a la carrera imperialista. Aun así, Silvela, a su vez, replicaba en el sentido de descartar también la política exterior aventurera, pero reafirmándose en la necesidad de entablar una alianza internacional:

Que no queremos la política de alianzas para las aventuras. Claro es que no. Loco, insensato, y criminal sería el que provocara alianzas para engrandecimientos territoriales inoportunos e innecesarios, para aventuras é influencias en Europa, en Asia ó en América, que no están en nuestros intereses ni en nuestros medios, pero para la defensa de lo que poseemos, para la defensa de lo que es nuestro, para prepararnos á las eventualidades del porvenir que puedan amenazárnoslo y disputárnoslo, para eso es imposible que niegue S.S. la conveniencia de tener un pensamiento definido de ponernos en una relación constante, fija, preconcebida, con los intereses que puedan ser armónicos en esa defensa. ¿Cree S.S. que tan sobrada de fuerzas está la Europa con sus grandes divisiones, que nuestro concurso y nuestra cooperación no pesan nada en la dirección de esos intereses?

En líneas generales, la tónica de este debate no fue sino la exposición y defensa de la política de recogimiento y neutralismo que se mantuvo durante toda la actuación política de Cánovas, estuviese en el poder o en la oposición. Ahora bien, la afirmación y aplicación aparente de esa doctrina no era — en realidad — más que una parte de la política real y

25. El Correo, Madrid, 9 de Agosto de 1896.

26. Véase Diego, Emilio de, «La España de...», cit.

27. D.S.C.D. 10 de Julio de 1896. 
completa de Cánovas, la cual iba más allá de lo señalado oficialmente. En efecto, si la apreciación de la situación europea y española le llevaba a la conclusión de la imposibilidad de que España se integrase en la política de alianzas de las grandes potencias, ello no le impidió buscar acuerdos e incluso alianzas, desde el comienzo del reinado de Alfonso XII, sobre puntos concretos con algunas de ellas cuando lo consideró factible y necesario, y sin que esas iniciativas empañasen su cuidado en mantener una posición digna e independiente de la nación pese a la relativa debilidad de ésta. Su constante dialéctica sobre el recogimiento, coincidente con las inclinaciones generales de la oligarquía política y de la opinión pública, no fue obstáculo para sus gestiones secretas a favor de compromisos sobre problemas determinados. Y sus advertencias y recomendaciones a los liberales sobre los peligros de una política pretenciosa y aventurada no le coartaron para aceptar y renovar pragmáticamente el convenio secreto con la Triple Alianza llevado a cabo por aquéllos una vez que lo juzgó aprovechable en las circunstancias del momento. Con todo, la innegable realidad es que esa política secreta fue algo fracasado e ineficaz frente al gran problema colonial que se planteó en la segunda mitad de los años 90: la defensa de los restos del Imperio. Se reveló entonces con toda crudeza la realidad de un aislamiento que no podía juzgarse sino como fruto de la «política aislacionista» de Cánovas. Esta situación, de hecho, se mostró de forma más aguda y dramática durante la última etapa de gobierno del político malagueño, es decir, desde 1895, cuando el criticismo a su política se hizo mayor ante la invencible dificultad que se iba encontrando en la guerra con Cuba. Se vio entonces, concretamente, en los debates parlamentarios de julio y agosto de 1896, lo difícil que era explicar una política de recogimiento negando su naturaleza aislacionista sin más, lo que llevó al ministro de Estado, duque de Tetuán, a una mala situación cuando trató de definir la política gubernamental como «ni de alianzas ni de aislamiento». Con todo, en secreto, la orientación política de la diplomacia restauracionista estaba registrando un cambio importante tras el conflicto de Melilla. ${ }^{28}$ Mientras que se llevaba a cabo un distanciamiento progresivo con respecto a los países de la Triple Alianza (al no querer estos comprometerse en la defensa de la españolidad de Cuba), se intentaba un reforzamiento de los lazos con Francia, Gran Bretaña y Rusia, ${ }^{29}$ en un momento histórico —en concreto, el año 1895- en el que Londres y París intentaban solucionar sus litigios coloniales en el valle del Nilo. ${ }^{30}$ Sin embargo, a la altura de 1896 las

28. Años antes, en Alemania se había venido evidenciando cómo al canciller Bismarck, la posición internacional del régimen restauracionista le despertaba tanto malhumor y tanta desconfianza que pasó de considerar prioritario apoyar a España en la cuestión marroquí, a descartar totalmente esa posibilidad. Resulta útil recordar a este respecto poco después los vanos esfuerzos del gobierno hispano por «activar» los lazos con la Triple Alianza en su favor durante la guerra de Melilla de 1893, y recibir como respuesta del gabinete de Berlín el consejo de que actuara con suma prudencia y de que la solución a los problemas de España pasaba por el acuerdo y el entendimiento con el Sultán marroquí. España siempre había quedado, por tanto, como un socio menor de Alemania en el complejo de los sistemas bismarckianos y también de menor confianza o de más dudosa fidelidad.

29. ARAH, Benomar, 9/ 7399, Ministro de Estado a Benomar, Madrid, 3 de Junio de 1896.

30. Robinson, Ronald E. y John Gallagher, «El reparto de África», en Historia del Mundo Moderno de la Universidad de Cambridge, tomo XI (El progreso material y los problemas mundiales. 1870-1898), Barcelona, Editorial Ramón Sopena, 1980, pp. 433 y 443. 
circunstancias variaron, y un acuerdo simultáneo de Madrid con Londres y París (y por ende, con San Petersburgo) fue prácticamente imposible desde el momento en que las rivalidades franco-británicas por el control del valle del Nilo se volvieron a acentuar. De hecho, Ahmed Ibrahim Abushouk señala al respecto que el 13 de marzo de 1896, el general en jefe de las fuerzas armadas británicas en Egipto, Kitchener recibía un telegrama ${ }^{31}$ informándole de que el gobierno británico autorizaba — ipor fin! tras la traumática caída de Jartum y la muerte de Charles Gordon años atrás - un avance del ejército egipcio hacia el sur, hacia el Sudán, y en concreto hacia Awasa, dentro del territorio mahdista. Con este movimiento, los británicos pretendían dar a sus amigos italianos una posición de ventaja en la región y al mismo tiempo debilitar la influencia de la III República en Abisinia y el mar Rojo. La reacción francesa fue apoyar a los etíopes en sus guerras contra los italianos, que fueron masacrados en la batalla de Adua. Este enfrentamiento francobritánico, al trastocarle sus planos, llevaría a Cánovas a redefinir más profundamente las vías del compromiso exterior de España, con una propuesta de alianza a Inglaterra, que no encontraría acogida alguna en Lord Salisbury, el primer ministro británico.

\section{La lectura de Silvela del proceso imperialista (1897-1899)}

La llegada al poder de los conservadores en 1899, tras el desastre colonial que había tenido que capear el gobierno Sagasta, iba a venir acompañada de un giro significativo en la dirección de la política exterior. El nuevo líder conservador — tras la muerte de Cánovas- F. Silvela era un firme partidario de terminar con la «política de aislamiento» que hasta entonces había llevado España. Por otra parte, el desastre del 98 había originado un cambio en los principios teóricos que informarían en adelante la política exterior del país: lo prioritario pasaba a ser ahora la seguridad del territorio nacional. Para ello, la garantía de los intereses españoles en el norte de África y en la cuestión de Marruecos en particular se presentaba como una cuestión fundamental que se imbricaba, en consecuencia, en la política de defensa.

En lo tocante a la proyección colonialista, el político conservador era perfectamente consciente de que el último tercio del siglo XIX había supuesto un cambio radical en las potencias europeas en lo relativo a la percepción del hecho colonial.

El 28 de octubre de 1897, Silvela pronunciaba una conferencia en la Asociación de la Prensa de Madrid titulada «La expansión colonial en los pueblos modernos». El político conservador realizaba una reflexión teórica sobre el fenómeno colonialista, y tras hacer una advertencia sobre la confusión existente entre la clase política española ante los nuevos derroteros que estaba experimentando el proceso colonial, propugnaba la necesidad urgente de formar una opinión pública informada antes de decidir la alineación u orientación internacional de España y la prosecución de su expansión colonial. Plenamente

31. Cf. Abushouk, Ahmed Ibrahim, «La rebelión mahdista», Desperta Ferro. Historia Moderna, n. ${ }^{\circ} 23$. Madrid, 2016, p. 14. 
consciente el conferenciante de los nuevos cambios históricos, se advertían en el discurso de Silvela influencias de autores contemporáneos. Es el caso del francés Lanessan, empedernido viajero y gobernador general de Indochina quien había introducido en 1886 en la publicística gala, siguiendo el ejemplo del británico Seeley, una mezcla en el discurso colonialista entre historia y antropología, en su obra L'expansion coloniale de la France. ${ }^{32}$ Así Silvela, siguiendo la estela de este autor, distinguía entre «pueblos y razas inferiores», con una función secundaria y pasiva en la Historia, y pueblos «superiores colonizadores y expansivos». La misión fundamental de los segundos era la de cumplir una función dirigente y hegemónica — «tutelar» la denomina Silvela — de los pueblos y razas que pertenecían a culturas más atrasadas, y evidenciar su superioridad militar, administrativa, económica y también moral..$^{33}$

El cambio de la coyuntura política internacional hacia 1880, una vez que el liberalismo político y también el económico empezaban a declinar, pues su objetivo - barrer los restos del Antiguo Régimen y permitir el desarrollo industrial— estaba cumplido, había venido consecuentemente acompañado de una sustitución de la ideología política de las clases dirigentes en Europa. La burguesía revolucionaria se había convertido en burguesía conservadora, y las ideas políticas liberales iban siendo sustituidas por el «nacionalismo» y sus ramificaciones más o menos radicales: conservadurismo, la devoción a la patria y a su condición de Estado soberano, ${ }^{34}$ militarismo, racismo, y en el Reino Unido por 'el socialdarwinismo británico', que hablaba de las naciones capacitadas para la lucha por la supervivencia, extrapolando las ideas evolucionistas de Charles Darwin a las cuestiones sociales y políticas. Tales peculiaridades transformaron el nacionalismo liberal de sus diez primeros lustros, defensor de la igualdad de las diversas naciones y su derecho a la autodeterminación, hasta convertirlo en una doctrina que proclamaba la disposición jerárquica de los Estados, de las razas y la superioridad de unos con respecto a otros. ${ }^{35}$ Esta aceptación del valor de las diferencias raciales se hacía sobre el trasfondo de una concepción del progreso concebido como evolución, idea común en la Europa de la segunda mitad del siglo XIX incluso compartida por teóricos anti-colonialistas como Robert Knox. En consecuencia, para Silvela la expansión colonial era ante todo el signo de la superioridad y de la fuerza de un país:

32. Para Lanessan, la historia ayudada por la antropología, nos muestra las razas divididas en dos categorías, la de las razas «ascendentes» y la de las razas «descendentes» o «estacionarias», a las que corresponden dos tipos de civilizaciones, las primarias y secundarias. Lanessan, Jean-Louis de, L'expansion coloniale de la France, París, 1886, pp. 3-23.

33. Cfr., Akmir, Youssef, «Marruecos previo a 1912: la injerencia europea entre la exploración etnológica y la intervención colonial», en Aragón Reyes, Manuel (dir.), El Protectorado español en Marruecos: la bistoria trascendida, vol. 1, Bilbao, Iberdrola, 2013, pp. 109-125.

34. Véase Morrow Jr, John H., La Gran Guerra, Barcelona, Edhasa, 1914, pág. 28 y siguientes.

35. El darwinismo social proporcionó así no pocos argumentos a las teorías belicistas, sobre la guerra y a otras agresiones del ser humano que interpretaban aquella como necesidad biológica y respuesta a las presiones evolutivas. Los humanos eran bravos y combativos, y quienes defendían esta postura aplicaban — de un modo demasiado literal y a menudo inapropiado - a los enfrentamientos a que daba lugar esta actitud las metáforas de la despiadada «lucha por la existencia», la «supervivencia del más fuerte» y la «ley de la selva». 
La expansión colonial es signo de superioridad y de fuerza, y la finalidad de esas creaciones que la expansión colonial produce no es, no debe ser la emancipación y la constitución de nacionalidades nuevas, sino la extensión de la nacionalidad de origen a otros continentes por medio de la comunión y enlace de intereses, de ideas, por medio de la representación eficaz y viva del genio nacional. ${ }^{36}$

El nuevo colonialismo, nacido pues del nacionalismo de índole racista, militarista, conservador y xenófobo dominante en Europa durante el último cuarto del siglo XIX se incardinaba a una concepción, la idea de la «misión histórica», típica del nacionalismo, la cual llevada hasta sus últimas consecuencias, conducía a una conclusión: que una raza, la blanca, o una determinada comunidad nacional estaban llamadas a cumplir una función dirigente y hegemónica frente a otras razas o pueblos, en especial si estos pertenecían a culturas más atrasadas. Los pueblos conquistados y sometidos se convirtieron, para los conquistadores europeos, en una prueba innegable de su superioridad étnica y moral. Los predicadores del colonialismo, así como no pocos imperialistas evangélicos, como es el caso de Rudyard Kipling, encubrieron el objeto de la explotación colonial con el disfraz de una nueva misión civilatrice, a cargo de la raza blanca, tal como denominaron los franceses el arrogante propósito de ilustrar a los nativos «salvajes». Estas ideas ligadas al «deber de las naciones blancas» están presentes en el pensamiento de Silvela, aunque con un tono muy tenue, casi desdibujado. Lógico. En todas las visiones literarias de la época imperialista se crea una auténtica mitificación, late la misma idea de fondo: la superioridad del hombre blanco, por su inteligencia, por sus recursos, por su valor respecto de los hombres de color, y por tanto la legitimidad intrínseca de la colonización. Ahora bien, en Silvela los desvelos del hombre blanco por cristianizar y civilizar a las llamadas «razas inferiores» están ausentes como motor o explicación del hecho imperial. El estadista conservador encuentra justificaciones al hecho imperial de otra índole, parangonables a lo que W. Baumgart o W.L. Langer calificaron como motivadoras de la «política de potencia».

Para Silvela, el proceso colonialista no era y no debía ser una actitud conducente a la tutela o al protectorado de las poblaciones extraeuropeas para que determinados pueblos llegasen a madurar políticamente, a evolucionar para en el futuro auto-determinarse y constituir naciones nuevas, gobernándose ellas mismas. Simplemente era la expresión de la vitalidad nacional del país colonizador: «No es el propio desenvolvimiento de la colonia [opinaba Silvela sobre lo que debe perseguir el colonialismo], sino la extensión verdadera de la nacionalidad, compenetrándose sus intereses materiales y morales con los de la patria de origen, y extendiendo esta noción, este sentimiento, esta fuerza a través de los mares y de los continentes». Pero Silvela no se limita a realizar la justificación del colonialismo basada simplemente en el prestigio y el poder. La grandeza de un Estado, y también

36. Véase Silvela de le Velleuze, Francisco, «La expansión colonial en los pueblos modernos». Conferencia pronunciada en la Asociación de la Prensa el 28 de octubre de 1897, en Silvela, Francisco, Artículos, discursos, conferencias y cartas, notas de Félix de Llanos y Torriglia, vol. 2, Madrid, Mateu, 1922-1923, pp. 412-422. 
su prosperidad económica y social, estribaban en el máximo afianzamiento de la comunidad de raza y de lengua entre las colonias y la metrópoli: un planteamiento que no era original de Silvela, sino tomado de Seeley. Pero en la nueva situación de finales del siglo XIX, perdido definitivamente el monopolio colonial británico, y en crisis el viejo sistema del «concierto europeo» que dictaba la dinámica de la política internacional, las relaciones internacionales eran percibidas sobre todo como rivalidades de colonialismos y lucha por esferas de influencia. El colonialismo no era pues sino una variante más de la «lucha por la vida», aplicada a las relaciones entre los Estados. Esto también se constataba en el discurso de Silvela: la carrera colonialista no es percibida como una mera cuestión de dignidad nacional, sino de una «lucha por la existencia» entre naciones, en la que la más pequeña cesión podría significar un paso hacia una irremediable decadencia.

Por otra parte, la posición de Silvela dentro del conservadurismo se vio reforzada considerablemente a partir del verano de 1898. Él había advertido públicamente que la guerra de Cuba acabaría en un desastre y que había que firmar la paz antes de que se produjera. El estallido de la «literatura regeneracionista» revalorizará su ya antiguo programa político y convertirá su larga disidencia frente a Cánovas en un acto de cordura y honradez. Al mismo tiempo era el único conservador capaz de dar una nueva imagen pública al partido. Por último, sólo él supo valorar el riesgo que suponían movimientos políticos, como el de las Cámaras de Comercio o el catalanismo, y fue capaz de reconducirlos hacia el conservadurismo, neutralizándolos y fortaleciendo el sistema político.

A principios de 1899 correspondía renovar la Junta Directiva del Círculo Conservador de Madrid. Alejandro Pidal, presidente saliente optó por no presentarse a la reelección y propuso a Silvela como nuevo responsable. Era al fin, el reconocimiento de su jefatura. Se iniciaba así una nueva etapa del conservadurismo español que coincidirá, cronológicamente, con el reinado de Alfonso XIII, teniendo como ideario político el programa «regeneracionista» que Silvela diseñó durante la década de los años 80, y como figura política más representativa a Antonio Maura. Próximo a ocupar la Jefatura del Gobierno, el 7 de Enero, al asumir la presidencia del Círculo conservador, Silvela realizaba un amplio discurso que podemos establecer como ideario político «regeneracionista» del nuevo gobierno que se iba a formar inmediatamente y donde su pensamiento en materia de proyección colonial y política exterior también tuvo cabida. Silvela anunciaba un reforzamiento acelerado del Ejército de Tierra y de la Armada, renunciando a recortar el aumento de los gastos militares («No podemos prometer al país un presupuesto de paz»), para no volver a asumir un repliegue en materia de política colonial. La defensa de las costas y de las fronteras sería una de las preocupaciones básicas del nuevo gobierno, así como la sustitución del material de guerra obsoleto y deficiente por nueva tecnología militar. Al mismo tiempo, Silvela señalaba la posición privilegiada de España, a caballo entre el Mediterráneo y el Atlántico, y punta europea propulsada sobre África como baza que había que aprovechar para reactivar la política exterior. No olvidaría en esta ocasión nuevas referencias al darwinismo social, y alentó al país a nuevos sacrificios para no renunciar a la expansión colonialista. Si no se seguía esta opción, España habría de renunciar a su papel de nación independiente y prepararse «a ser un mero territorio explotado 
y administrado por gerentes extranjeros». ${ }^{37}$ Tanto este discurso como el de 1897 contenían ya indicaciones claras de cual iba a ser su actuación en la jefatura del gobierno.

Su primera preocupación en materia de política exterior iba a ser garantizar la plena integridad del territorio nacional, incluyendo las Baleares y Canarias. Sobre estas últimas, Emilio de Ojeda, responsable de la Legación diplomática hispana en Tánger había advertido al gobierno sagastino durante el verano de 1898 y en reiteradas ocasiones en relación con los hipotéticos movimientos ingleses tendentes a apoderarse del archipiélago.

Tal y como ha indicado José María Jover, la condensación de tensiones coloniales que presenta la última década del siglo XIX es posible estudiarla bajo el prisma de primer intento serio de redistribución colonial, parcialmente consumado con la particularidad de que los territorios coloniales objeto de la redistribución no son todavía los poseídos ya por las grandes potencias imperialistas, sino los poseídos por antiguas potencias coloniales que llevaron a cabo su expansión mundial en etapas históricamente anteriores, y que comparecen en la época del imperialismo sin el poderío material — desarrollo económico e industrial, ejércitos y armadas - necesario para mantener su dominio sobre tales áreas en un momento en que otros son los dueños del mundo. ${ }^{38}$ Las dos potencias coloniales que van a ver sus respectivos imperios sometidos, en 1898, a sendos planos de reparto van a ser Portugal y España. Uno de estos proyectos —el relativo a Portugal— quedará en amago, no exento, comenta Jover, de prolongadas consecuencias diplomáticas. El otro —relativo a España - surgiría, sobre la marcha, a partir de unos movimientos emancipadores intervenidos por los Estados Unidos, y tendría efectividad en beneficio de esta última potencia y de Alemania. La situación en que iban a quedar aquellas dos viejas potencias coloniales tras las duras crisis de los años noventa plantearía el problema de una «garantía» internacional que asegurase la continuidad del status territorial de estos países en una fase histórica en que habían comenzado a escala internacional a primar manifiestamente, las relaciones de fuerza. En los círculos diplomáticos se expandía la idea de que la redistribución territorial podía afectar incluso al propio ámbito peninsular e insular español. Era un reto que el gabinete conservador debía afrontar.

Una de las primeras decisiones de política exterior del nuevo gobierno conservador fue la de terminar con el contencioso de las fortificaciones levantadas por los españoles cerca de Gibraltar, en el contexto de 1898. La iniciativa hispana se materializó el 15 de marzo de 1899 en una Nota formal presentada al gobierno de Londres; el gabinete español renunciaba a las obras de fortificación por deferencia y amistad al Reino Unido sin reconocer la existencia de ningún derecho británico que le obligase a hacerlo. Parece evidente que Silvela consideró que la actuación política emprendida anteriormente por el tándem Sagasta/Almodóvar (Ministro de Estado sagastino) era insuficiente para garanti-

37. Véase Silvela de le Velleuze, Francisco, «En la Presidencia del Círculo Conservador: El programa (Discurso pronunciado el 7 de Enero de 1899)», en Silvela, Francisco, Artículos..., cit., pp. 510-511.

38. Véase Jover Zamora, José M.. ${ }^{2}$ «1898. Teoría y práctica de la redistribución colonial», en Juliá, Santos, Debates en torno al 98: Estado, Sociedad y Política, Madrid, Consejería de Educación Comunidad de Madrid, 1998, p. 21. 
zar la seguridad española frente a los peligros de la política británica. El Gobierno conservador prefirió buscar la normalización de las relaciones entre Madrid y Londres renunciando a las fortificaciones a través de un procedimiento diplomático discreto, un intercambio de Notas, en las que cada una de las partes declaraba formalmente sus intenciones. Aunque la iniciativa de Silvela mejoró las relaciones hispano-británicas, la mejora fue relativa ya que ni la opinión pública española olvidaba el comportamiento inamistoso del gobierno de Londres durante la guerra hispano-estadounidense, ni tampoco el compromiso español de desmontar las fortificaciones de la bahía de Algeciras se llevó a la práctica con la premura que hubiesen deseado los británicos. ${ }^{39}$

$\mathrm{Y}$ es que los recelos del gobierno conservador hacia las posibles amenazas que las actuaciones del gabinete de Lord Salisbury pudieran suponer para el territorio nacional o el escaso remanente colonial que le quedaba a España en África vinieron incentivados cuando se produjo una filtración del proceso negociador anglo-germano que debatía el reparto de las colonias portuguesas en el continente africano. A pesar del hermetismo que rodeaba a las negociaciones, propio de la diplomacia ultrasecreta del período anterior a la I Guerra Mundial, a finales de marzo llegaba a Madrid desde Lisboa la noticia de una serie de conversaciones entre el II Reich y el gabinete británico que comportaban planes y proyectos de reparto con respecto al imperio colonial portugués. Las noticias que la Legación diplomática española en la capital lusa había recabado insistían en el interés particular de Gran Bretaña sobre Lorenzo Marques, en una coyuntura especialmente difícil como era la que atravesaba Portugal desde el punto de vista financiero que hacía previsible, si cuajaba el acuerdo anglo-germano, el desmembramiento de sus colonias africanas. El Gobierno luso había tenido constancia de tales negociaciones, pero desconocía el alcance de las mismas y si existía un texto resolutorio. ${ }^{40}$

Sin embargo, no se llegó a una efectiva redistribución de las colonias portuguesas situadas al sur del Ecuador. Siguieron adscritas a la formalmente indiscutida soberanía de

39. La interferencia de Gibraltar en la política exterior de España durante los años anteriores al 98 , la puso ya de relieve Federico Curato en La questione marocchina e gli accordi mediterranei italo-spagnoli del 1887 e del 1891, vol. 1 y 2, Milán, Edizioni di Comunitá, 1961-1964. Para la crisis del 98 y sus repercusiones ver Torre del Río, Rosario de la, Inglaterra y España en 1898, Madrid, Eudema, 1988; Torre del Río, Rosario de la, «La seguridad del área del Estrecho de Gibraltar como condicionante de la política exterior española en la crisis de 1898», en Cortés, María Teresa, Consuelo Naranjo y José Alfredo Uribe (coords.), El Caribe y América Latina: el 98 en la coyuntura imperial, tomo 1, Morelia, Universidad Michoacana de San Nicolás de Hidalgo, 1998, pp. 47-73; Robles Muñoz, Cristóbal, «España y el equilibrio mediterráneo (1890-1891)», Hispania, n. ${ }^{\circ}$ 208, Madrid, 2001, pp. 149-183; Robles Muñoz, Cristóbal, «Il confronto europeo nel Mediterraneo occidentale», Rivista Storica Italiana, vol. 112, n. ${ }^{\circ}$ 2, Napoli, 2000, pp. 703-741; Robles Muñoz, Cristóbal, «Italia y España: la crisis de 1891 en Portugal y el Mediterráneo occidental», en Rassegna Storica del Risorgimento, vol. 80, n. ${ }^{\circ} 4$, Città di Castello, 2000, pp. 539-576; Robles Muñoz, Cristóbal, «Guerra de Melilla y reajustes en Europa (18931894)», Hispania, n. ${ }^{\circ}$ 203, Madrid, 1999, pp. 1033-1061; Robles Muñoz, Cristóbal, «Entre Francia e Italia. El acuerdo verbal hispano-italiano de 1895», Hispania, n. ${ }^{\circ}$ 192, Madrid, 1996, pp. 291-322; Robles Muñoz, Cristóbal, «España y las alianzas europeas en 1898», Hispania, n. ${ }^{\circ}$ 197, Madrid, 1997, pp. 479-514.

40. Archivo General de la Administración (en adelante AGA). Real Orden del Ministerio de Estado de 11 de Abril de 1899 dirigida al Embajador de España en Londres, Conde de Rascón., Asuntos Exteriores. Embajada en Londres, 7.021 / 198. 
Lisboa, aunque sobre tal soberanía gravitase la tácita hipoteca de — siguiendo la terminología de Lord Salisbury en el famoso discurso de la Primrose League- un acuerdo de principio entre dos «living nations». Finalmente la monarquía lusa logró capear el peligro y recibir una garantía de seguridad nacional, refrendando su secular dependencia con respecto a la Gran Bretaña, mediante la declaración secreta anglo-portuguesa de 14 de Octubre de 1899: el Tratado de Windsor.

Teniendo como referencia el caso contemporáneo de Portugal, y como fórmula de prevención ante una dinámica que arrastrase a España a una situación similar, Silvela propuso en abril a Francia una alianza continental, en la que debían entrar también Rusia y Alemania, destinada a garantizar la integridad territorial de la península, islas y posesiones africanas, a cambio del concurso militar de España «para una acción común en Europa y África». ${ }^{41}$ Sin embargo, ni las posibilidades de solución de las tradicionales diferencias franco-alemanas eran tantas como podía calcular el Gobierno español, ni los intereses de la Dúplice con España, aun excluyendo a Alemania, eran suficientes como para suscribir un compromiso de semejante envergadura.

\section{Silvela y Marruecos}

El año 1899 supuso la vuelta al poder de los conservadores, ocupando F. Silvela la presidencia del gabinete. Dotado de una fina perspicacia para entender que se estaba produciendo un cambio apreciable en la dinámica colonial, lo suficientemente importante como para que pudiera hablarse de una nueva etapa en ella; consciente de que al margen de los beneficios económicos, reales o ensoñados, de los imperios territoriales, había otra cara de la ilusión imperial, tal como la experimentaban no sólo el público europeo en general, sino también los diversos gobiernos del momento: la de verla como una condición de grandeza y de potencia $;{ }^{42}$ sabedor - por tanto- de un principio ampliamente aceptado en la época, el de que un país no alcanzaba el grado y el prestigio de gran potencia, hasta que no llegaba a poseer extensos territorios colonizados en el mundo, Silvela se propuso obrar en consecuencia. En un sentido más amplio, además, el gabinete conservador entendía la necesidad de marcar un nuevo rumbo a su política exterior como consecuencia de la lección asumida al haberse tenido que enfrentar el país a Estados Unidos en la más absoluta soledad internacional, haber perdido dramáticamente los restos del viejo Imperio y experimentar el temor a que los efectos del desastre se extendieran a las Canarias y

41. Las conversaciones de la primavera de 1899 entre los gobiernos de Francia y Alemania con vistas a integrar un frente con Rusia para contrarrestar la preponderancia naval de Gran Bretaña fueron apuntadas hace ya más de cincuenta años por William Langer, que también reseñaba la participación del gobierno español en la promoción de esta estratagema política. Cfr. Langer, William, The Diplomacy of Imperialism, 1890-1902, Nueva York, Alfred A. Knopf, 1951, p. 600. Véase asimismo Marín Castán, María F., «La política exterior española entre la crisis de 1898 y la dictadura de Primo de Rivera», en VVAA, La política exterior española en el siglo XX, Madrid, Ediciones de las Ciencias Sociales, 1994, p. 24.

42. Como acertadamente diría Lytton Strachey: «El Imperialismo es a la vez una fe y un negocio». 
a la bahía de Algeciras y sin una flota numerosa para defender las costas e islas nacionales y los enclaves africanos. Sin duda, el principal objetivo debía ser conseguir una garantía internacional que impidiese nuevas pérdidas, que ahora podrían afectar a los territorios de la región del Estrecho de Gibraltar. Si se tiene en cuenta el comportamiento inamistoso de los ingleses durante la guerra con Estados Unidos, la crisis de las fortificaciones de la bahía de Algeciras y la oferta de Londres de un tratado de satelización de España respecto a los intereses británicos, se entenderá perfectamente que Silvela pensara en Francia. Por ello, en un auténtico giro radical en la actuación concerniente a Marruecos, rompió con la política anterior —ensayada por Sagasta — de acercamiento al Reino Unido.

Tras haberse esforzado en mejorar las relaciones con Inglaterra — renunciando a las fortificaciones de la bahía de Algeciras y afirmando su deseo de mantener el statu quo en Marruecos-, la política exterior de Silvela pasó a lo largo de 1899 por una aproximación a la Dúplice franco-rusa, buscando un ingreso de España en esta alianza militar ${ }^{43}$ que garantizase la integridad territorial española, amenazada por el ciclo de la redistribución colonial de finales del siglo XIX. ${ }^{44}$ Por ello la diplomacia hispana no buscó poner freno a la expansión armada republicana iniciada en el sureste del Sultanato, a partir de Argelia, a finales de 1899. Era un modelo de política que buscaba la concertación o acuerdo con París y que huía de protagonizar actuaciones provocativas u hostiles a los ojos de Francia, en el septentrión africano. La Dúplice Alianza, empero, no deseaba compromisos militares con España. En consecuencia, Silvela rectificó entonces su política marroquí.

Cuando el Majzén (= gobierno central del Sultanato) quiso suturar las posibles brechas que pudieran existir en el septentrión marroquí, susceptibles de ser utilizadas por los franceses o españoles en sus tareas de infiltración en el Imperio jerifiano, planteó a la comunidad internacional la necesidad de limitar drásticamente los intercambios comerciales en aguas del Rif. ${ }^{45}$ Silvela se enfrentó entonces a la mayor parte de las potencias

43. O en una alianza continental que agrupase a Francia, Rusia, Alemania y España. La propuesta de Silvela a los gobiernos francés, ruso y alemán en Torre, Rosario de la, «La crisis de 1898 y el problema de la garantía exterior«, Hispania, vol. 46, n. ${ }^{\circ}$ 162, Madrid, 1986, pp. 115-165; Álvarez Gutiérrez, Luis, «El contexto internacional del noventa y ocho», en Naranjo, Consuelo, Miguel Ángel Puig-Samper y Luís Miguel García Mora (eds.), La nación soñada: Cuba, Puerto Rico y Filipinas ante el 98, Madrid, Doce Calles, 1996, pp. 713-728.

44. La propuesta transmitida al Ministro de Exteriores francés en abril de 1899: «En el primer rango de nuestros aliados naturales está Francia, a la que no separamos de Rusia. Nos gustaría unirlas a Alemania porque nos parece que una entente sobre tan amplias bases sería la más sólida garantía del mantenimiento de la paz, pues bastaría realmente para hacer fracasar las ambiciones inglesas sin necesidad de recurrir a un conflicto armado». Si la inclusión de Alemania en el bloque propuesto no fuera posible, Silvela se declaraba dispuesto a unirse, en cualquier caso, a Francia y Rusia: «Nosotros les pediríamos que nos garantizasen la integridad de nuestros territorios actuales, comprendiendo en ellos nuestras posesiones africanas, poniendo a cambio, a su servicio, si fuera necesario, las fuerzas militares de las que pudiésemos disponer». El proyecto de Silvela buscaba, pues, la garantía exterior de la integridad española en la formación de un esquema de alianzas posible: la reconciliación de Francia y Alemania y la combinación de estos dos países junto con Rusia para contrarrestar la preponderancia naval británica. Cfr. Torre, Rosario de la: «Madrid cambia de baraja. La carta francesa», La aventura de la Historia, n. ${ }^{\circ} 87,2006$, p. 42.

45. El Majzén buscaba cortar las actividades de contrabando en la zona. Véase Correale, Francesco, Échange et contrebande d'armes au Maroc et dans a région Sabaro-Mauritainienne entre 1912 et 1918, Tesis de Historia para la obtención del grado de Doctor de la Universidad, Université de Provence, 2003. 
europeas que se oponían a la medida del Majzén. ${ }^{46}$ Sin embargo, esta iniciativa autónoma de la diplomacia española en la cuestión marroquí, que buscaba respaldar al Majzén, necesitaba contar con apoyos en Europa. Por ello, el gabinete conservador buscó franca y abiertamente el consorcio con el Reino Unido, posibilidad rechazada por Londres. ${ }^{47}$

A finales de 1899 el Majzén continuó su estrategia de reforzar la soberanía imperial en las costas rifeñas. Acosó a los protegidos hispanos en las cabilas de la zona, a los confidentes de las guarniciones españolas enclavadas en el territorio y culminó su actuación bloqueando los puestos de Alhucemas y Peñón de Vélez de la Gomera. ${ }^{48}$ El Majzén, consciente del trance ocasionado a España por las derrotas coloniales recientes, pretendía borrar la presencia extranjera en el Rif, echar a los españoles al mar. La ambición colonialista no había constituido, hasta entonces, en la praxis, la preocupación dominante del gobierno conservador. Sin embargo, este incidente fue despertando los deseos de Silvela de llevar a cabo una expansión territorial en Marruecos, no concebida directamente como una revancha por la humillación de 1898, sino más bien como una vía para encontrar un binterland defensivo en las costas marroquíes para España. Inquieto por la suerte de las guarniciones, el estadista conservador llegó a esbozar la idea de desencadenar una acción armada en el Rif, ${ }^{49}$ aunque la idea finalmente quedó descartada cuando, tras intensas gestiones diplomáticas por parte del Ministerio de Estado, las fuerzas imperiales marroquíes levantaron el bloqueo.

En otro orden de cosas, la arremetida militar francesa contra el Tuat —Sáhara oriental marroquí- a finales de $1899^{50}$ redefinió a corto plazo los objetivos de las potencias imperialistas en el Sultanato, incitando a cada una de ellas a formular sus aspiraciones respectivas en la zona. La diplomacia española permaneció expectante durante unas semanas; finalmente Silvela fue ensayando otra política, más prudente y moderada, supeditando las actuaciones diplomáticas en el Imperio jerifiano a la previa aceptación de las mismas por parte de las naciones europeas representadas diplomáticamente en el Imperio marroquí. Así, el Ministerio de Estado entabló contacto con diversas cancillerías con el fin de conseguir un consenso a la hora de presentar ante el Majzén una nota de rechazo a la paralización de las obras de un lazareto en Sawira (Mogador), que estaba siendo levantado bajo supervisión española. ${ }^{51}$

46. AGA. África. Marruecos, 122/.6. Telegrama del Presidente del Gobierno y Ministro de Estado, F. Silvela a Emilio de Ojeda. 4 de noviembre de 1899; Ibidem. Real Orden del Ministerio de Estado núm. 147 dirigida a la Legación española en Tánger. 3 de noviembre de 1899.

47. AGA. Asuntos Exteriores. Embajada de España en Londres. 7016/181-bis. Embajador de España en Londres al jefe de Gobierno. Despacho núm. 3. 11 de enero de 1900.

48. AGA. África. Marruecos., 84 /.1. Oficio del gobernador de la guarnición de Alhucemas, Anastasio Terrón dirigido al Comandante General de Melilla. 3 de octubre de 1899.

49. AGA, África, Marruecos 354 / 3. Real Orden número 17 del Ministerio de Estado dirigida a la Legación de España en Tánger. 6 de febrero de 1900.

50. Cfr. Robles Muñoz, Cristóbal, La política exterior de España. Tomo 1: Una política mediterránea, occidental y de paz (1899-1905), Madrid, Consejo Superior de Investigaciones Científicas, 2006, p. 135.

51. AGA, Asuntos Exteriores, Embajada de España en Londres, 7003. Despacho núm. 379 del Ministerio de Estado dirigido al Embajador.12 de noviembre de 1899. 


\section{La ofensiva diplomática española de $\mathbf{1 9 0 0}$}

Ante la ruptura de hecho del statu quo marroquí por parte de los franceses, ocasionada por la invasión del Tuat, Silvela no atendió las peticiones de ayuda que efectuó el Majzén a las naciones europeas en dos ocasiones distintas. ${ }^{52}$ Las escaramuzas en el extremo suroriental del Imperio jerifiano no causaban — por otro lado- ningún entusiasmo en el Ministerio de Estado: desde 1885, la diplomacia española había venido siempre entendiendo que una invasión del Tuat significaba un ataque frontal contra el Sultanato de Marruecos. Pero ahora ninguna nación iba a hacer frente común con España para apoyar las reivindicaciones marroquíes. No tenía sentido, en este contexto, oponerse frontalmente desde Madrid a la estrategia francesa de intervención militar. Las pretensiones galas sobre el Tuat no constituían, por otra parte, una amenaza concreta para los gobiernos restauracionistas españoles, los cuales nunca habían tenido intereses territoriales en el Sáhara Oriental. Silvela reaccionó, a sugerencia de Emilio de Ojeda, diseñando una limitada ofensiva colonial que buscaba instrumentalizar en beneficio de España el desconcierto del gobierno marroquí tras la agresión militar gala. Silvela obró en esta ocasión, de nuevo, diseñando una acción autónoma en el Sultanato y trató de obtener del Majzén que éste cediese a la Marina de Guerra española la facultad de vigilar las aguas del Sus, es decir, aquellas que permitían una defensa adelantada del archipiélago canario. ${ }^{53}$

Fracasado este intento, la ofensiva de Silvela entró en una segunda fase. La conclusión de un acuerdo con el gobierno de la Tercera República sobre Río de Oro el 27 de junio de 1900 dejó pendiente el tema de la frontera meridional del Imperio jerifiano. De hecho, el malestar y el temor del gobierno de Silvela porque Francia no quiso aceptar delimitar la frontera norte de Río de Oro en el convenio, y reconocer la marroquinidad de la Saqîa al-Hamra y Tarfaya, ${ }^{54}$ llevó al presidente del Consejo de Ministros español a reconsiderar su política exterior con objeto de garantizar los intereses de España; o sea, evitar a toda costa que cualquier otra nación (léase Francia) se estableciera entre la frontera sur del reino de Marruecos y la colonia de Río de Oro, con el fin de salvaguardar la seguridad de las islas Canarias. Silvela pensaba que los franceses podían llevar a cabo una ocupación del territorio comprendido entre el Uad Draa y el cabo Bojador ${ }^{55}$ y hacerse con el control de la costa enfrentada a Canarias. En ese contexto, la posesión del territorio al sur del Draa pasó a ser tras un titubeo inicial el principal objetivo estratégico de la diplomacia española durante el verano de $1900 .^{56}$ De hecho, el gobierno conservador

52. AGA, África. Marruecos, 73/2, Emilio de Ojeda al Ministro de Estado. 20 de junio de 1900. Despacho núm. 75; Ibidem. Ojeda a Aguilar de Campoó. 30 de agosto de 1900. Despacho núm. 99.

53. AGA, África. Marruecos, 62/ 1. Carta reservada del Presidente del Gobierno y Ministro de Estado, Francisco Silvela a Emilio de Ojeda. 2 de abril de 1900.

54. Vilar, Juan Bautista, «Guinea y Sahara Atlántico, objetivo colonial sustitutorio de Cuba antes y después de 1898», en VVAA, Castilla y el 98, Zamora, UNED, 2000.

55. AGA, África. Marruecos, 123 / 2. Carta particular núm. 5 del Ministro de Estado a Emilio de Ojeda. 23 de junio de 1900.

56. AGA, África, Marruecos, 62 /1. Carta particular del subsecretario de Estado, Pérez Caballero al Ministro de Estado. 15 de agosto de 1900. 
planteó a su homólogo jerifiano la posibilidad de que España renunciara a sus derechos sobre Ifni a cambio de Tarfaya, utilizando como argumento un posible plan de la Tercera República para ocupar el territorio al sur del Uad Draa.

Los sucesivos intentos realizados para obtener la concesión del territorio por parte del Sultán Abd al-Aziz fracasaron ${ }^{57}$ y obligaron a Silvela, dado que el fin justifica los medios, a buscar incluso el apoyo del Reino Unido. En el primer contacto con el jefe del gabinete británico, lord Salisbury, el embajador español en Londres, Duque de Mandas, intentó convencerlo de que su gobierno no dificultase las negociaciones que el representante español en Marruecos iba a proseguir con el Majzén, en un momento en el que Gran Bretaña estaba más pendiente de la guerra con los boers en Sudáfrica y de los problemas en China. Asimismo, el Ministerio de Estado buscó posteriormente que Londres intercediese en favor del gobierno restauracionista para que el Sultán accediese a entregar Tarfaya y la Saqîa al-Hamra, la enorme región donde Silvela deseaba que se crease un nuevo Imperio colonial hispano. La diplomacia española argumentó ante Lord Salisbury su temor a que el Sultán no fuese capaz de mantener el control sobre los territorios del sur del Imperio y a que el equilibrio político en la zona se rompiese si se producía un desembarco de fuerzas francesas en la región. ${ }^{58}$ Tras una primera negativa del mandatario británico, el 26 de junio de 1900, lord Salisbury notificaba a Madrid que no tenía inconveniente alguno en que España intentara la permuta de Ifni por Tarfaya. Esta «veleidad sahariana» de Silvela, como la ha calificado Martínez Milán, ${ }^{59}$ no era sino «la vertiente en política exterior de lo que constituía el "regeneracionismo" aplicado por el jefe de los conservadores en la política interior». Sin embargo, la administración de Mawlay Abd al-Aziz se siguió negando a dicho trueque. Lejos de desfallecer, Silvela inició en septiembre conversaciones tanto con el Reino Unido como con otras potencias, incluida Francia, para convencerlas de que presionaran al joven sultán a fin de que aceptara la propuesta de cambio. Finalmente, un mes más tarde, el gobierno británico se negó a respaldar las pretensiones hispanas: la voluntad española de controlar la vasta región al sur del Draa hacía inevitable, a corto plazo, el fin del statu quo y la desintegración del Imperio marroquí, circunstancia ésta que los estrategas del Foreign Office deseaban evitar a toda costa.$^{60}$ En consecuencia, Londres no podía darse por satisfecha con la amputación territorial de una parte del Sultanato, deseada por Silvela, quien a pesar de que afirmaba oficialmente estar dispuesto a defender el statu quo de Marruecos, sin embargo de facto planteaba - a juicio de los británicos— unas actuaciones diplomáticas que tenían un marcado carácter agresivo, aspirando a sacar partido de la descomposición del Imperio jerifiano. ${ }^{61}$

57. Ayache, Germain, Etudes d'bistoire marocaine, Rabat, S.M.E.R, 1979, pp. 343-344.

58. AGA. Asuntos Exteriores. Embajada de España en Londres. 7016 / núm. 181-bis. Telegrama del Ministro de Estado dirigido al Embajador de España en Londres. 25 de junio de 1900.

59. Martínez Milán, Jesús, «España y Francia en el sur de Marruecos...», cit., p. 125.

60. AGA. Asuntos Exteriores, Embajador de España en Londres al Ministro de Estado. Despacho núm. 167. 12 de octubre de 1900.

61. De hecho, el ministro plenipotenciario británico en Tánger, Arthur Nicolson, argumentó que su país 


\section{Conclusiones. Consideraciones en torno a la «errática» política del gobierno Silvela respecto a la cuestión marroquí en el bienio 1899-1900}

La política exterior del jefe de gobierno conservador, F. Silvela durante el bienio 18991900 en lo tocante a la cuestión marroquí puede ser interpretada a simple vista como muy errática. Tras la derrota frente a Estados Unidos, que había puesto de relieve la precariedad de la política internacional del régimen restauracionista, en 1899 buscó primero una alianza con Francia, para en el verano de 1900, echarse en brazos de Inglaterra, confiando en el respaldo del gobierno británico para constituir un nuevo imperio colonial en el continente africano, que tuviese como base el control de los territorios de Tarfaya y la Saqîa al-Hamra. Sin embargo estos bandazos en las orientaciones exteriores esconden que, en definitiva, Silvela se movía siempre en virtud de la búsqueda de una garantía internacional para la integridad territorial de España, o de un apoyo exterior que permitiese la constitución de un binterland defensivo de la península y del archipiélago canario, que se situaba en el noroeste del continente africano.

En consonancia con lo apuntado, en lo categórico, sus manifestaciones públicas y sus escritos de la época aluden claramente a la asunción de la derrota colonial en el Caribe y el Pacífico, combinada con la mala conciencia de la tarea inconclusa por no haber sabido pergeñar una estructura defensiva más completa en aras a asegurar la seguridad nacional. En ese sentido, en sus últimos escritos, entrevistas y otras intervenciones públicas se retoma el discurso sobre la necesaria eliminación para el país de las consecuencias morales y de los factores vivientes que no han asimilado la derrota —en definitiva se propone la amnesia histórica sobre la pérdida de los últimos restos coloniales-al mismo tiempo que se incita inconscientemente al lector o al público hacia la conclusión de que si bien Cavite y Santiago supusieron la derrota física de una serie de elementos, derivados de la mala planificación diplomática del conflicto con los norteamericanos, constituyeron en cambio la solidificación moral de un país, que podía ahora rehacer su Historia. En este sentido y en el terreno de la praxis, es decir de lo operativo, el líder conservador concentró todos sus esfuerzos en luchar contra el aislamiento exterior de España, bien «moviéndose» con el objetivo de encontrar apoyos internacionales, alianzas, de buscar solidaridades, bien inclinándose hacia el reforzamiento de las estructuras militares nacionales, intentando la construcción de un pequeño imperio no tanto buscando su explotación económica, sino más bien una mejor estructuración de la defensa del país. Si quiso que España ingresase en la Dúplice franco-rusa fue con ese propósito; si intentó posteriormente apoderarse de Tarfaya y la Saqîa al-Hamra ello respondió al mismo objetivo: conseguir un estratégico glacis o zona de seguridad en la costa occidental de Marruecos que permitiese una mejor defensa militar del archipiélago canario.

Por lo tanto sus actuaciones - como ha señalado Antonio Niño- difieren mucho de la consideración de diplomacia insegura, vacilante y timorata con la que ha sido acusado

no era favorable a la permuta porque la tesis de la ocupación francesa no tenía sentido, dada la pobreza de la región y la hostilidad de las tribus. 
(esa era la visión que se tenía de la política internacional practicada por Silvela, hasta el período en torno a 1996-1997). Sabedor de la dinámica histórica imperante, el agresivo imperialismo, Silvela, a sugerencia del Ministro plenipotenciario español en Tánger, Emilio de Ojeda procuró huir de la satelización de España con respecto a los intereses galos, e intentó a finales de la primavera de 1900 sorprender a la comunidad internacional con una maniobra diplomática repentina e inesperada que devolviese al país su condición de colonizador y una posición de prestigio respetada por toda Europa. Esta maniobra no la llevó a cabo de manera completamente abierta, apoyándose en una influyente opinión pública nacional que respaldase su actuación: su intento se inscribió más bien en la política hermética, de diplomacia secreta de detrás de las escaleras, propia del continente europeo en el período anterior a la Primera Guerra Mundial, intentando repetir la fórmula francesa — modelo a imitar — de jugar con hechos consumados en la cuestión marroquí. La información y el debate quedaron excluidos, pues, del Parlamento.

Para ello el gabinete español negoció directamente con el Majzén en un primer momento sin dar cuenta de sus gestiones a ningún país. ${ }^{62}$ De hecho, tal maniobra se frustró por la oposición del Sultán a la cesión de Tarfaya, y en una segunda etapa, Silvela dio a conocer sus propósitos a las principales cancillerías europeas. A lo largo del verano, todas las negociaciones intentadas por el gabinete conservador en Marruecos en aras a la ocupación de la costa sahariana al norte de Río de Oro no tuvieron éxito. La documentación diplomática española nos evidencia cómo el gobierno deseaba obtener la ocupación de Tarfaya y la Saqîa por miedo a que la región pasara a estar controlada por el Reino Unido o Francia; sobre todo por parte de los franceses. El miedo al «peligro francés» fue usado constantemente como un instrumento por los españoles ante el Sultán con el fin de forzar la concesión. Las tácticas dilatorias del Majzén frustraron la acción diplomática hispana ${ }^{63}$ y obligaron a los conservadores a decantarse por la búsqueda de apoyos exteriores que permitiesen la consecución de esas pretenciosas e importantes ambiciones territoriales. Un año después del conflicto diplomático suscitado por el asunto de Gibraltar y en un claro bandazo de sus inclinaciones exteriores, Silvela buscó en el Reino Unido el apoyo necesario para construir un imperio colonial en el noroeste de África. El Gobierno conservador, utilizando el manido recurso de esgrimir la posibilidad de la ocupación de Tarfaya-Saqîa por parte de Francia, intentó que el primer ministro británico, lord Salisbury se convirtiese en el medio apropiado para intentar romper la cerrazón del Sultán. ${ }^{64}$ Este apoyo fue prometido por parte británica en un primer momento, y posteriormente negado tras un estudio exhaustivo de lo que significaba por parte del Foreign Office, coincidiendo con la llegada a este departamento ministerial del nuevo responsable, lord Lansdowne, por considerarlo claramente atentatorio al mantenimiento de la independencia de

62. AGA, África, Marruecos, 62/1. Carta particular del sub-secretario de Estado, Pérez Caballero al Ministro de Estado, Marqués de Aguilar de Campoo. 15 de agosto de 1900.

63. Véase Ayache, Germain, Etudes d'bistoire marocaine..., cit., pp. 343-344.

64. AGA, Asuntos Exteriores. Embajada de España en Londres, 7016/181-bis. Telegrama de Aguilar de Campoo dirigido al Duque de Mandas, Embajador de España en Londres. 25 de junio de 1900. 
Marruecos y a la pervivencia del statu quo. ${ }^{65} \mathrm{El}$ rechazo inglés llevará a los gobiernos conservadores a sondear a Francia, en otro giro de los que marcan la aparentemente errática política exterior española. La documentación de la Embajada española en París patentiza que en octubre de 1900, manifiesto ya el rechazo británico, el gobierno de Madrid se dirige al Ministro francés de Asuntos Exteriores, T. Delcassé, ${ }^{66}$ buscando el apoyo de la República ${ }^{67}$ para sus pretensiones sobre el sur del Imperio jerifiano. ${ }^{68}$ Estas charlas entre el Embajador español en París, Fernando León y Castillo ${ }^{69}$ y Delcassé son el prefacio inmediato de las negociaciones franco-españolas sobre el reparto de todo el Sultanato que se iniciarán en la primavera de 1901. Era el fin de una trayectoria iniciada a comienzos de año. Con ella Silvela no había conseguido potenciar la trayectoria expansionista del país, ni afirmar las pretensiones españolas en Marruecos, ni siquiera ganarse la voluntad francesa o británica en aras a garantizar la seguridad nacional sin olvidar que se iba constatando la creciente potencialidad bélica de Francia, instalada ya en ciertas partes del Sultanato, no enormemente peligrosas para la sensibilidad española o europea en general, pero apuntando a ulteriores movimientos expansionistas. Atendiendo al marco teórico descrito por Roberto $\mathrm{Mesa}^{70}$ cuando distingue entre las grandes potencias cuya política es de irradiación mundial, de aquellas medianas que ejercen un importante función protagonista, aunque nunca hegemónica, en un radio de acción limitado, concretamente regional, ${ }^{71}$ Silvela había buscado en 1900 que España se moviera u obrara dentro de los parámetros de esta última categoría, la definida por un país con una política internacional propia, es decir, adecuada a sus proposiciones y eficaz en cuanto a sus objetivos.

65. Ibidem. Duque de Mandas al Marqués de Aguilar de Campoó. Despacho núm. 167. 12 de octubre de 1900.

66. La figura de Théophile Delcassé debe ser especialmente resaltada en calidad de artífice del proceso de cerramiento de la expansión colonial francesa en el norte de África. A Delcassé se debe aproximadamente esta percepción del tema: «En lo concerniente a Marruecos, tengo particular interés en diferenciar su dimensión internacional de la dimensión franco-marroquí; y en ajustar la primera por separado y sucesivamente con cada potencia con vistas a disponer finalmente de plena libertad para ajustar la segunda directamente con Marruecos». Documents Diplomatiques Francaises (en adelante DDF): 1871-1914. París. Ministére des Affaires Etrangéres, 2d. serie, V.II, n. ${ }^{\circ} 17$, pp. 438-459. Véase asimismo Morales Lezcano, Víctor, León y Castillo, Embajador (1887-1918). Un estudio sobre la política exterior de España, Las Palmas de Gran Canaria, Ediciones del Cabildo Insular de Gran Canaria, 1975.

67. Para el marco contextual de las negociaciones franco-españolas sobre el reparto de Marruecos, debe consultarse Delaunay, Jean-Marc, Méfiance cordiale. Les relations franco-espagnoles de la fin du XIX siècle à la Première Guerre mondiale. Volume 2. Les relations coloniales, París, L'Harmattan, 2010.

68. AGA, África, Marruecos, 73/2. León y Castillo, Embajador de España en París al Marqués de Aguilar de Campo. Despacho reservado núm. 334. 25 de octubre de 1900.

69. Para ahondar en el contexto previo a la consecución del Protectorado español en Marruecos, están los trabajos de Rouard de Card y Saint-René Taillandier; desde el ángulo español, véanse de León y Castillo, Fernándo, Memorias. Mis Tiempos, vols. 1 y 2, Tenerife, Eds. del Cabildo Insular de Gran Canaria, 1976 y Romanones, Conde de, Las responsabilidades políticas del Antiguo Régimen (1875-1913), Madrid, Renacimiento, 1924, dos testimonios ineludibles. Véase asimismo, Morales Lezcano, Víctor, León y Castillo, Embajador..., op. cit.

70. Véase Mesa, Roberto, Democracia y política exterior en España, Madrid, Eudema, 1988, p. 17.

71. Cfr. Allain, Jean-Claude, La Moyenne Puissance au XXe siècle. Recherche d'une définition, París, PUF, 1988 
La frustrada experiencia de Silvela de aproximación al Reino Unido iba a marcar la política española con respecto a la cuestión marroquí. A finales de año, el estadista fue sustituido en la presidencia del gabinete por el general Azcárraga, quien encabezó un gobierno del partido conservador hasta dar paso, en la primavera de 1901, a los liberales de Sagasta. Como acabamos de señalar, Aguilar de Campoo, Ministro de Estado con Silvela y con Azcárraga, tras tomar nota del rechazo británico a las pretensiones saharianas de la diplomacia española, acudió a buscar la ayuda francesa para obtener Tarfaya y la Sagîa. Cuando en el Quai d'Orsay el Embajador español en París, León y Castillo, inició las conversaciones con el Ministro de Exteriores galo, Delcassé, éste propuso al gabinete de Azcárraga que el diálogo franco-español no se centrase en una región del Sultanato, sino que se extendiese al futuro de todo el Imperio marroquí. ${ }^{72}$

\section{Bibliografía}

\section{Fuentes:}

Archivo General de la Administración (AGA)

Archivo de la Real Academia de Historia (ARAH)

Diario de Sesiones de las Cortes. Congreso de Diputados (DSC)

Documents Diplomatiques Françaises (DDF)

El Correo, Madrid, 9 de Agosto de 1896

\section{Referencias bibliográficas:}

Abdelhamid, Smaili Moulay, Les années terribles du Maroc oriental, 2 vol., Oujda, BMFI, 1996.

Abushouk, Ahmed Ibrahim, «La rebelión mahdista», Desperta Ferro. Historia Moderna, núm. 23, Madrid, 2016, pp. 12-16.

Akmir, Youssef, «Marruecos previo a 1912: la injerencia europea entre la exploración etnológica y la intervención colonial», Aragón Reyes, Manuel (dir.), El Protectorado español en Marruecos: la historia trascendida, vol. 1, Bilbao, Iberdrola, 2013, pp. 109-125.

Álvarez Gutiérrez, Luis, «El contexto internacional del noventa y ocho«, en Naranjo, Consuelo, Miguel Ángel Puig-Samper y Luis Miguel García Mora (eds.), La nación soñada: Cuba, Puerto Rico y Filipinas ante el 98, Madrid, Doce Calles, 1996, pp. 712-728.

Allain, Jean-Claude, La Moyenne Puissance au XXe siècle. Recherche d'une définition, París, 1988.

Anta Ugarte, Javier, Gonzalo de Reparaz: intelectual errante, Tesis doctoral inédita, Barcelona, Universitat de Barcelona, 2016.

Arranz, Luis, «El liberalismo conservador en la Europa continental, 1830-1939: los casos de Francia, Alemania e Italia», Revista de Estudios Políticos, núm. 102, Madrid, 1998, pp. 59-76.

72. AGA, África, Marruecos, 73 /Ex. 2. Embajador de España en París al Ministro de Estado. Despacho reservado núm. 334. 25 de octubre de 1900. 
-, «Los liberal-conservadores y la consolidación del régimen constitucional en la España del siglo XIX», Historia contemporánea, núm. 17, Bilbao, 1998, pp. 169-188.

—, «La Restauración, 1875-1902: el triunfo del liberalismo integrador. Cánovas y Silvela», en Marco, José María (coord.), Genealogía del liberalismo español, 1875-1936, Madrid, FAES., 1998.

—, «Francisco Silvela (1845-1905) y las incertidumbres del "regeneracionismo" conservador», en Rus Rufino, Salvador y Javier Zamora Bonilla (coords.), Una polémica y una generación. Razón bistórica del 1898, León, Universidad de León, 1998, pp. 33-38.

—, Escritos y discursos políticos de Francisco Silvela y de la Vielleuze, Madrid, Centro de Estudios Políticos y Constitucionales, 2005.

—, «Silvela, Maura y el revisionismo conservador», en Pendás García, Benigno, Antonio Maura, en el centenario del "Gobierno Largo", Madrid, FAES, 2007, pp. 63-98.

Ayache, Germain, Etudes d'bistoire marocaine, Rabat, S.M.E.R., 1979.

Bendaoud, Abdelwahed y Mohammed Maniar (eds.), Tánger 1800-1956. Contribution à l'bistoire recente du Maroc, Rabat, Éditions Arabo-africaines, 1981.

Brett, Michael, «Great Britain and the Southern Morocco in the Nineteenth Century», Journal of North African Studies, vol. 2, núm. 2, Londres, 1997, pp. 1-10.

Burke III, Edmund, Prelude to Protectorate in Morocco. Precolonial protest and resistance, 18601912, Chicago/Londres, University of Chicago Press, 1976.

Clemente Ortega, Ángel Luis y José Ignacio de Frutos Blas, «Francisco Silvela y Marruecos: un proyecto de política exterior», Isla de Arriarán. Revista Cultural y Científica, núm. 14, Málaga, 1999 , pp. 226-254.

Correale, Francesco, Échange et contrebande d'armes au Maroc et dans a région Saharo-Mauritainienne entre 1912 et 1918, Tesis de Historia presentada para la obtención del grado de Doctor, Université de Provence, 2003.

Curato, Federico, La questione marocchina e gli accordi mediterranei italo-spagnoli del 1887 e del 1891, vol. 1 y 2, Milán, Edizioni di Comunitá, 1961-1964.

Dardé Morales, Carlos, «Los conservadores ante la crisis de 1898: el regeneracionismo de Francisco Silvela», en Homenaje a D. José Luis Comellas, Sevilla, Universidad de Sevilla, 2000, pp. 185200.

Delaunay, Jean-Marc, Méfiance cordiale. Les relations franco-espagnoles de la fin du XIX siècle à la Première Guerre mondiale: Volume 2: Les relations coloniales, París, L'Harmattan, 2010.

Diego, Emilio de, «La España de 1896», en Hacia el 98. La España de la Restauración y la crisis colonial, 1895-1898), Madrid, Cuadernos de la Escuela Diplomática/12, 1997.

García Sanz, Fernando, Historia de las relaciones entre España e Italia. Imágenes, comercio y política exterior (1890-1914), Madrid, C.S.I.C., 1993.

Gómez Ochoa, Fidel, «Francisco Silvela en la historiografía contemporánea. El impacto del centenario de su muerte y el "Estudio introductorio" de Luis Arranz a los Escritos y discursos políticos», Historia y Política, núm. 22, Madrid, 2009, pp. 261-278.

Jover Zamora, José M. ${ }^{a}$, «1898. Teoría y práctica de la redistribución colonial», en Juliá, Santos, Debates en torno al 98: Estado, Sociedad y Política, Madrid, Consejería de Educación Comunidad de Madrid, 1998.

Lanessan, Jean-Louis de, L'expansion coloniale de la France, París, 1886.

Langer, William, The Diplomacy of Imperialism, 1890-1902, Nueva York, Alfred A. Knopf, 1951.

Lou, Gabriel, Alfonso XIII, Madrid, Círculo de Amigos de la Historia, 1976.

Marín Castán, María F., «La política exterior española entre la crisis de 1898 y la dictadura de Pri- 
mo de Rivera», en VVAA, La política exterior española en el siglo XX, Madrid, Ediciones de las Ciencias Sociales, 1994, pp. 19-46.

Martínez Carreras, José U., «La política exterior española durante la Restauración, 1875-1931», en Vilar, Juan Bautista (ed.), Las relaciones internacionales en la España contemporánea, Murcia, Ediciones Universidad de Murcia, 1989, pp. 79-100.

Martínez Milán, Jesús María, «España y Francia en el sur de Marruecos: intereses, delimitación de fronteras y contencioso territorial, 1900-1912», Estudios de Asia y África, vol. 50, núm. 1, México D.F., 2015, pp. 117-139.

Mesa, Roberto, Democracia y política exterior en España, Madrid, Eudema, 1988.

Miège, Jean-Louis, Le Maroc et l'Europe, 1830-1894, vol. 4, París, Presses Universitaires de France, 1964.

Morales Lezcano, Víctor, León y Castillo, Embajador (1887-1918). Un estudio sobre la política exterior de España, Las Palmas de Gran Canaria, Ediciones del Cabildo Insular de Gran Canaria, 1975.

Morrow Jr., John H., La Gran Guerra, Barcelona, Edhasa, 1914.

Parsons, Frederick V., The origins of the Morocco question, 1880-1900, London, Duckworth, 1976.

Portero, Florentino, «Francisco Silvela, jefe del conservadurismo español», Revista de Historia Contemporánea, núm. 2, Universidad de Sevilla, 1983, pp. 146-166.

—, «El regeneracionismo conservador: el ideario político de Francisco Silvela», Tusell, Javier, Feliciano Montero y José María Marín (eds.), Las derechas en la España contemporánea, Madrid, UNED/Anthropos, 1997, pp. 45-58.

-, «El conservadurismo español ante la crisis de fin de siglo», Tusell, Javier y Florentino Portero (eds.), Antonio Cánovas y el sistema político de la Restauración, Madrid, Biblioteca Nueva, 1998, pp. 349-392.

Robinson, Ronald E. y John Gallagher, «El reparto de África», en Historia del Mundo Moderno de la Universidad de Cambridge, tomo XI (El progreso material y los problemas mundiales. 18701898), Barcelona, Editorial Ramón Sopena, 1980.

Robles Muñoz, Cristóbal, «Entre Francia e Italia. El acuerdo verbal hispano-italiano de 1895», Hispania, núm. 192, Madrid, 1996, pp. 291-322.

—, «España y las alianzas europeas en 1898», Hispania, núm. 197, Madrid, 1997, pp. 479-514.

—, «Guerra de Melilla y reajustes en Europa (1893-1894)», Hispania, núm. 203, Madrid, 1999, pp. 1033-1061.

—, «Il confronto europeo nel Mediterraneo occidentale», Rivista Storica Italiana, vol. 112, núm. 2, Napoli, 2000, pp. 703-741.

—, «Italia y España: la crisis de 1891 en Portugal y el Mediterráneo occidental», Rassegna Storica del Risorgimento, vol. 80, núm. 4, Città di Castello, 2000, pp. 539-576.

—, «España y el equilibrio mediterráneo (1890-1891)», Hispania, núm. 208, Madrid, 2001, pp. 149-183.

Rubio, Javier, «La política exterior de Cánovas del Castillo: una profunda revisión», Studia Histórica. Historia Contemporánea, núm. 13-14, Universidad de Salamanca, 1995-1996, pp. 167-197.

_, El final de la era de Cánovas. Los preliminares del «desastre» de 1898, vol. 1 y 2, Madrid, Biblioteca Diplomática española, 2004.

—, «Los primeros años del reinado de Alfonso XII: su compleja problemática nacional e internacional», Anales de Historia Contemporánea, núm. 23, Universidad de Murcia, 2007, pp. 507 560. 
Salom Costa, Julio, «La política exterior y ultramarina de Cánovas», en Bullón de Mendoza, Alfonso y Luis E. Togores (coords.), Cánovas y su época, t. II, Madrid, Fundación Cánovas del Castillo, 1999, pp. 1087-1136.

Seco Serrano, Carlos, «Regeneracionismo y tensiones sociales (en torno al Gobierno Silvela de 1899-1900)», Estudios de Historia Moderna y Contemporánea, núm. 113, Madrid, 1978, pp. 221-268.

—, «Los silvelistas catalanes: notas para su estudio», Estudios históricos, núm. 1, Madrid, 1990, pp. 169-198.

-, Historia del conservadurismo español. Una línea integradora en el siglo XIX, Madrid, Temas de Hoy, 2000.

—, «Francisco Silvela: el regeneracionismo ético. Homenaje en su centenario», Boletín de la Real Academia de la Historia, vol. 202, núm. 2, Madrid, 2005, pp. 185-195.

Silvela de le Velleuze, Francisco, «La expansión colonial en los pueblos modernos». Conferencia pronunciada en la Asociación de la Prensa el 28 de octubre de 1897, en Silvela, Francisco, Artículos, discursos, conferencias y cartas, notas de Félix de Llanos y Torriglia, vol. 2, Madrid, Mateu, 1922-1923, pp. 412-422.

—, «En la Presidencia del Círculo Conservador: El programa (Discurso pronunciado el 7 de Enero de 1899)» en Silvela, Francisco, Artículos, discursos, conferencias y cartas, notas de Félix de Llanos y Torriglia, vol. 2, Madrid, Mateu, 1922-1923, pp. 510-511.

Torre Gómez, Hipólito de la, «El destino de la “regeneración” internacional de España (18981918)», en Proserpina, 1, Especial Monográfico «Relaciones Internacionales de España en el siglo XX», Mérida, UNED, diciembre de 1984.

Torre del Río, Rosario de la, «La crisis de 1898 y el problema de la garantía exterior», Hispania, vol. 46, núm. 162, Madrid, 1986, pp. 115-165.

—, Inglaterra y España en 1898, Madrid, Eudema, 1988.

—, «La seguridad del área del Estrecho de Gibraltar como condicionante de la política exterior española en la crisis de 1898», en Cortés, María Teresa, Consuelo Naranjo y José Alfredo Uribe (coords.), El Caribe y América Latina: el 98 en la coyuntura imperial, tomo I, Morelia, Universidad Michoacana de San Nicolás de Hidalgo, 1998, pp. 47-73.

—, «Entre amenazas e incentivos. España en la política internacional, 1895-1914», Studia Histórica. Historia Contemporánea, núm. 24, Universidad de Salamanca, 2006, pp. 231-256.

—, «Madrid cambia de baraja. La carta francesa», La aventura de la Historia, núm. 87, Madrid, 2006, pp. 40-45.

Vilar, Juan Bautista, «Guinea y Sahara Atlántico, objetivo colonial sustitutorio de Cuba antes y después de 1898», en VVAA, Castilla y el 98, Zamora, UNED, 2000. 